\title{
UM NOVO MAPA DA INDÚSTRIA TEXTIL NA EUROPA
}

\author{
JOACHIM THIEL ${ }^{1}$
}

$\mathrm{O}$ «Observatório Europeu de Têxteis e Vestuário» é uma instituição europeia que tem como objectivo principal apoiar as empresas da União Europeia (UE) com actividade nestes ramos industriais, sobretudo através do fornecimento de informação quantitativa sobre a evolução das áreas relacionadas com os têxteis e o vestuário. Para além das publicações periódicas, o Observatório encomenda ocasionalmente estudos especiais destinados a preencher lacunas em domínios que não são suficientemente explorados pelos dados habitualmente recolhidos. A internacionalização da produção de vestuário é um desses domínios dificilmente acessível em termos de informação segura. Todavia, quem analisa atentamente a origem da sua roupa, ainda que de alta qualidade, fica surpreendido com as viagens pelo mundo que as peças fazem antes de serem usadas pelo consumidor.

É principalmente na análise dessas viagens, e mais propriamente das estratégias empresariais que estão na sua base, que o estudo dirigido pelo Dr. Michael Scheffer, técnico da Associação Holandesa da Indústria de Vestuário e Malha, quer assentar $^{2}$. Actualizando um trabalho anterior do autor, 165 produtores de vestuário de seis países europeus (Holanda, Alemanha, Bélgica, França, Itália e Inglaterra) e 53 empresas têxteis de sete países europeus (os mesmos mais Portugal) foram entrevistados, através de questionários enviados por correio, a fim de estudar o seu comportamento face a uma «nova divisão internacional do trabalho» em que os países em vias de desenvolvimento assumem um papel muito mais activo, constituindo assim uma forte concorrência para os produtores da UE.

A seguir a uma parte teórica em que se mostram os efeitos deste fenómeno, assim como os seus actores principais (sobretudo o comércio retalhista como importador, no capítulo 1.2, merece a atenção do leitor) na reestruturação do sector e os principais caminhos da internacionalização (representados por conceitos como «Sourcing», «Subcontraction», «Foreign production» e «Outward Processing Trade $(O P T) »)$, desenvolvem-se dois vectores principais para conceptualizar as estratégias empresariais: o nível da integração da produção, isto é, a percentagem da produção dentro da própria empresa, e o nível da deslocalização, isto é, a percentagem da produção dentro do próprio país. A partir destes vectores é possível identificar quatro estratégias fundamentais de produção de vestuário: produção dentro da empresa, dentro e fora do país; e subcontratação, dentro e fora do país. Mas também é possível agrupar as empresas entrevistadas segundo as estratégias que têm perseguido ao longo da última década (1983-1992). Seis tipos de empresas foram identificados: as «firmas integradas», as «global producers», as «global sourcers» e os pequenos produtores tipo «Terceira Itália», como grupos extremos neste contexto, mais dois tipos intermédios: as «firmas em transição» e os «price mixers», estes últimos procurando, de certa forma, subsidiar a produção própria através de produção parcialmente deslocalizada.

\footnotetext{
${ }^{1}$ Investigador da rede EUNIT no Centro de Estudos Geográficos da Universidade de Lisboa. Centro de Estudos Geográficos, Faculdade de Letras, Cidade Universitária, 1699 LISBOA CODEX. Tel.: (351-1) 7940218; Fax: (351-1) 7938690; e-mail: ceg@ mail.telepac.pt

2 SCheffer, M. (1994) - The changing map of European textiles. Production and sourcing strategies of textile and clothing firms. L'Observatoire Européen du Textile et de l'Habillement, Bruxelas, 160 páginas.
} 
Esta esquematização é, em princípio, a parte fundamental de todo o estudo e parece contribuir para um entendimento mais sistematizado da actual reestruturação industrial. Ligar uma dimensão organizativa e uma dimensão territorial, como é feito, é o primeiro passo para compreender a lógica de uma «produção industrial 'pós-industrial'». Mas um dos problemas do estudo em questão reside no facto de, com poucas excepções, a análise ficar limitada a esta lógica industrial. A tendência de concentração organizativa, sobretudo por parte do comércio e da distribuição de vestuário, que, a nosso ver, constitui a força principal dentro do sistema da produção de moda, é mencionado de uma forma demasiado marginal. Neste sentido, valeria a pena estudar não só a componente reactiva das empresas industriais face à ameaça da globalização, mas também a lógica activa da globalização em si.

A tipologia de empresas, estabelecida a partir das estratégias diferentes, por sua vez, serve de base para os perfis nacionais dos seis países estudados. Neste contexto, é interessante ver que as diferenças entre os países são, por um lado, substanciais e, por outro lado, assentam muito na história do sector. Enquanto na Itália e na Bélgica, e de uma forma mais restrita em França, as empresas optaram principalmente pela subcontratação dentro do país e pelo estilismo, na Inglaterra a reestruturação tem sucedido na maioria dos casos pelo upgrading técnico, visto que a origem do sector estava intimamente ligada à Revolução Industrial. Assim, em 1992, no Reino Unido, $74 \%$ dos produtores de vestuário eram ainda firmas verticalmente integradas. Em contrapartida, a Holanda e a Alemanha afirmavam-se como os campeões na deslocalização para fora do país, com $37 \%$ e $34 \%$ das empresas, respectivamente, dentro dos grupos dos «global producers» ou «global sourcers» e só $29 \%$ e $26 \%$ de firmas integradas. O que também é notável, no caso da Alemanha, é que os «price-mixers» formavam o maior grupo.

Após esta parte empírica central, o estudo procura explorar alguns domínios, em torno das tendências anteriormente detectadas, que deverão influenciar as estratégias empresariais no futuro. O título da secção sumária desta parte «Segunda geração: produção no estrangeiro» já diz muito dos resultados: toda a estrutura europeia da produção de vestuário aponta para um crescente reforço da internacionalização da produção apesar de existirem algumas evoluções contrárias, como a necessidade de responder depressa às alterações do mercado.

As entrevistas com as 53 empresas oriundas do sector têxtil (exclusivamente produção de tecidos) formam a parte final do livro. Estuda-se, por um lado, em que medida a fabricação de tecidos segue a mesma lógica que a produção de véstuario e, por outro lado, o impacto da internacionalização da última sobre a primeira. Os resultados principais são que raramente existem as pré-condições para que os fornecedores dos tecidos sigam os produtores de vestúario no sentido de formar «clusters» no estrangeiro. A direcção da produção de vestuário a partir da Europa facilita a permanência. Deslocalização da produção de tecidos sucede em geral segundo lógicas diferentes, seja ao abrigo da alianças estratégicas com o comércio, seja para produzir para mercados extra-europeus.

O estudo é fundamental já que não há muito material estatístico sobre este fenómeno dentro de um sector ainda muito importante na União Europeia e principalmente em Portugal. Pena é que os países comunitários onde o sector ainda cresceu na segunda metade dos anos oitenta, como Portugal e Grécia, não sejam quase considerados. 